medRxiv preprint doi: https://doi.org/10.1101/2021.10.04.21264228; this version posted October 5, 2021. The copyright holder for this

preprint (which was not certified by peer review) is the author/funder, who has granted medRxiv a license to display the preprint in It is made available under a CC-BY-NC-ND 4.0 International license .

\title{
Influence of sex, season and environmental air quality on experimental human pneumococcal carriage acquisition
}

Katerina S. Cheliotis ${ }^{1}$, Christopher P. Jewell ${ }^{2}$, Carla Solórzano ${ }^{1}$, Britta Urban ${ }^{1}$, Andrea M. Collins ${ }^{1}$, Elena Mitsi ${ }^{1}$, Sherin Pojar ${ }^{1}$, Elissavet Nikolaou ${ }^{1}$, Esther L. German ${ }^{1}$, Jesús Reiné ${ }^{1}$, Stephen B. Gordon ${ }^{1,3}$, Simon P. Jochems ${ }^{1}$, Jamie Rylance ${ }^{1}$, Daniela M. Ferreira ${ }^{1 *}$

${ }^{1}$ Department of Clinical Sciences, Liverpool School of Tropical Medicine, Liverpool, United Kingdom

${ }^{2}$ CHICAS, Lancaster University, Bailrigg, Lancaster, United Kingdom

${ }^{3}$ Malawi-Liverpool-Wellcome Trust Clinical Research Programme, Blantyre, Malawi

*Corresponding author: Daniela.Ferreira@Istmed.ac.uk

\begin{abstract}
Streptococcus pneumoniae (pneumococcus) is the most common identified bacterial cause of pneumonia, and the leading infectious cause of death in children under five years of age worldwide. Pneumococcal disease follows a seasonal pattern with increased incidence during winter. Pneumonia burden is also associated with poor air quality. Nasopharyngeal carriage of the bacterium is a pre-requisite of invasive disease.
\end{abstract}

We aimed to determine if susceptibility to nasopharyngeal pneumococcal carriage varied by season, and which environmental factors might explain such variation. We also evaluated the influence of sex on susceptibility of carriage. We collated data from five studies in which human volunteers underwent intranasal pneumococcal challenge. Generalised linear mixed effects models were used to identify factors associated with altered risk of carriage acquisition, specifically climate and air-quality data.

During 2011-2017, 374 healthy adults were challenged with type 6B pneumococcus. Odds of carriage were significantly lower in males (OR, 0.61;95\% Cl, 0.40-0.92; $p=0.02$ ), and higher with cooler temperatures $(\mathrm{OR}, 0.79 ; 95 \% \mathrm{Cl}, 0.63-0.99 ; \mathrm{p}=0.04)$. Likelihood of carriage also associated with lower concentrations of local fine particulate matter concentrations $\left(\mathrm{PM}_{2.5}\right)$ and increased local rainfall.

In contrast to epidemiologic series, experimental challenge allowed us to test propensity to acquisition during controlled exposures; immunologic explanations for sex and climatic differences should be sought. 
medRxiv preprint doi: https://doi.org/10.1101/2021.10.04.21264228; this version posted October 5, 2021. The copyright holder for this preprint (which was not certified by peer review) is the author/funder, who has granted medRxiv a license to display the preprint in It is made available under a CC-BY-NC-ND 4.0 International license .

\section{Introduction}

Infection with Streptococcus pneumoniae (pneumococcus) is characterised by initial colonisation in the nasopharynx. Nasopharyngeal carriage of pneumococcus is also the source of human-to-human transmission [1], with point prevalence estimated at $45-66 \%$ of infants and $<10 \%$ of adults [1-3]. Most frequently, this is a transient state, although subsequent pathogenic infection can occur encompassing a spectrum of severity from selfresolving otitis media to life-threatening sepsis. The burden of pneumonia is particularly high; S. pneumoniae is the commonest identified bacterial pathogen. It is associated with a three-fold higher risk of mortality than non-pneumococcal pneumonia [4, 5], and is the major contributor to the annual 880,000 child pneumonia deaths [6].

Invasive pneumococcal disease is seasonal with peaks in winter most obvious in adult groups [7], and pneumococcal carriage rates in infants are significantly higher in cooler and drier months [8]. Around half of child pneumonia deaths have been attributed to poor air quality [6]. Short-term exposure to naturally occurring particulate matter (PM) has previously been associated with increased risk of hospital admission due to pneumonia, particularly in the elderly [9]. However, a more recent study involving univariate analysis showed that $\mathrm{PM}$ with a mean aerodynamic diameter $\leq 2.5 \mu \mathrm{m}\left(\mathrm{PM}_{2.5}\right), \mathrm{PM}_{1}$ and $\mathrm{PM}_{10}$, along with relative humidity, temperature and solar radiation, were inversely correlated with rates of pneumococcal infection [10]. Conversely, $\mathrm{SO}_{2}, \mathrm{NO}_{x}, \mathrm{NO}_{2}, \mathrm{NO}$ and $\mathrm{CO}$ were found to be positively correlated with pneumococcal infection.

The experimental pneumococcal challenge programme in Liverpool (UK) provides data on the propensity to colonisation after instillation of S. pneumoniae into the nose. This offers a unique opportunity to study the seasonal and other factors which determine carriage given a known exposure timepoint and bacterial density. We used systematically collected data and participant demographics across several experimental studies to answer two main questions: Does the rate of susceptibility to nasopharyngeal pneumococcal carriage acquisition change throughout the year? Do environmental parameters affect carriage acquisition?

\section{Methods}

A meta-analysis was conducted using data of five clinical trials carried out at the Clinical Research Unit, Liverpool School of Tropical Medicine between November 2011 and March 2017. All studies were approved by the sponsors and the North West NHS Research Ethics Committee (REC numbers: 11/NW/0592, 15/NW/0146, 14/NW/1460, 12/NW/0873). Inclusion criteria for all the studies were any person who spoke fluent English and was between the age of 18 and 50, except for 11/NW/0592, which had an upper age limit of 60 . Exclusion criteria for the trials were contact with at risk individuals, current smoker or significant smoking history ( $>10$ pack years), asthma or respiratory disease, chronic illness, pregnancy, penicillin allergy, involved in another clinical trial unless observational or in follow-up (non-interventional) phase and unable to give fully informed consent. None of the 
medRxiv preprint doi: https://doi.org/10.1101/2021.10.04.21264228; this version posted October 5,2021 . The copyright holder for this preprint (which was not certified by peer review) is the author/funder, who has granted medRxiv a license to display the preprint in It is made available under a CC-BY-NC-ND 4.0 International license.

volunteers had received a pneumococcal vaccine. All volunteers provided written informed consent.

Participants were inoculated in each nostril with serotype 6B pneumococcus as previously described, with carriage defined as detection at any follow-up timepoint of serogroup 6 pneumococcus by classical microbiology with latex agglutination testing [11]. Follow-up sampling was performed over 1 month.

Contemporaneous air-quality data files from Speke, Liverpool were available from the Department for Environment Food \& Rural Affairs. These data included measurements of air-quality determinants $\left(\mathrm{PM}_{2.5}, \mathrm{PM}_{10}\right.$, volatile $\mathrm{PM}_{10}$, volatile $\mathrm{PM}_{2.5}$, non-volatile $\mathrm{PM}_{2.5}$, ozone, $\mathrm{NO}, \mathrm{NO}_{2}, \mathrm{NO}$ as $\mathrm{NO}_{2}$ and $\mathrm{SO}_{2}$ ) which were similarly summarised as monthly averages for the period. Seasonality of climate and air quality data was confirmed (Supplementary Figures 1 and 2).

Regional climate data were obtained for 2011-2017 from the nearest Meteorological Office facility (located 69 miles West of Liverpool in Valley, Anglesey). Environmental data measurements were averaged for each climatic variable for every month of each year, including maximum and minimum temperatures $\left({ }^{\circ} \mathrm{C}\right)$, rainfall $(\mathrm{mm})$ and sun hours.

All data analysis and modelling were carried out using $R$ software ( $R$ version 3.4.2). Studies were initially analysed using separately constructed generalised linear models. However, due to small sample sizes, data were pooled using a generalised linear mixed-effects (GLME) model, accounting for study effect, represented by the formula:

$$
\operatorname{Logit}\left(p_{i j}\right)=\log \left(\frac{p_{i j}}{1-p_{i j}}\right)=\alpha+\chi_{i j}^{\top} \beta+u_{j}
$$

where $\alpha$ is a random intercept for each individual and $u_{j}$ accounts for study effect

it is reasonable to assume that $u \sim \operatorname{Normal}\left(0,{ }^{2}\right)$.

Collinear variables were expected from climate and air-quality measures (Supplementary Figures 3 and 4); $\mathrm{NO}$ as $\mathrm{NO}_{2}$, volatile $\mathrm{PM}_{2.5}$, volatile $\mathrm{PM}_{10}$ and non-volatile $\mathrm{PM}_{2.5}$ were removed from the model to improve accuracy. Temperature measurements were represented in the model by the daily minimum. Where there was limited collinearity, but a strong prior evidence of association with carriage, variables were maintained in the model ( $\mathrm{PM}_{2.5}$ and $\mathrm{PM}_{10}, \mathrm{SO}_{2}$ and $\mathrm{NO}$ and $\mathrm{NO}_{2}$ ). The GLME model included sex, age (categorical), inoculation month, minimum temperature, temperature difference, rainfall, sun hours, $\mathrm{PM}_{10}, \mathrm{PM}_{2.5}$, ozone, $\mathrm{NO}, \mathrm{NO}_{2}$ and $\mathrm{SO}_{2}$. Where models did not converge, scaling was applied to covariates using the scale function in $\mathrm{R}$ [12]. Backwards elimination was used to remove non-informative variables and model fit was determined by minimising Akaike information criterion (AIC). Interactions between variables were assessed and covariance of model terms was determined using the 'vcov' function in the package 'MASS'. Intraclass correlation (ICC) was generated using the 'ICC' function in the package 'sjstats'. 
medRxiv preprint doi: https://doi.org/10.1101/2021.10.04.21264228; this version posted October 5, 2021. The copyright holder for this preprint (which was not certified by peer review) is the author/funder, who has granted medRxiv a license to display the preprint in It is made available under a CC-BY-NC-ND 4.0 International license .

\section{Results}

Study Cohort Demographics

Between November 2011 and March 2017, 407 volunteers were intranasally inoculated with pneumococcus serotype 6B across five clinical trials (Table 1, Figure 1). Natural carriers (carriage of non-serogroup 6 pneumococcus) were excluded from analysis (33/407 volunteers). Hence, a total of 374 volunteers were included in our analysis, 210 volunteers $(56.2 \%)$ were female. Of these 374 volunteers, 171 (45.7\%) became colonised. Most volunteers were recruited from university campuses in Liverpool and average volunteer age was 22 (87.7\% of participants were aged 18-25). Most data were collected during winter months (October-March; 329/374) (Table 1). 
medRxiv preprint doi: https://doi.org/10.1101/2021.10.04.21264228; this version posted October 5, 2021. The copyright holder for this preprint (which was not certified by peer review) is the author/funder, who has granted medRxiv a license to display the preprint in It is made available under a CC-BY-NC-ND 4.0 International license .

Table 1: Demographics data for each clinical trial and pooled data.

\begin{tabular}{|c|c|c|c|c|c|c|c|}
\hline Study & $\begin{array}{l}\text { Study } \\
\text { Description }\end{array}$ & $\begin{array}{l}\text { Number of } \\
\text { Volunteers }\end{array}$ & $\begin{array}{l}\text { Average } \\
\text { Age } \\
\text { (years) }\end{array}$ & $\begin{array}{l}\text { Sex } \\
\text { Balance }\end{array}$ & $\begin{array}{l}\text { Inoculation } \\
\text { Months for } \\
\text { Study } \\
\text { (number of } \\
\text { volunteers) }\end{array}$ & $\begin{array}{l}\text { Carriage } \\
\text { Rate (\%) }\end{array}$ & $\begin{array}{l}\text { Average } \\
\text { Inoculation } \\
\text { Dose (CFU) }\end{array}$ \\
\hline 11/NW/0592 & $\begin{array}{l}\text { To establish } \\
>40 \% \\
\text { carriage using } \\
\text { Spn6B }{ }^{1} \text { and } \\
{\text { Spn } 23 F^{2} \text {; }}_{\text {participants }} \\
\text { inoculated } \\
\text { with Spn6B } \\
\text { included in } \\
\text { this analysis } \\
\text { (started } \\
\text { 2011) }\end{array}$ & 86 & $\begin{array}{l}23 \\
\text { (IQR 22- } \\
34)\end{array}$ & $\begin{array}{l}49 \\
(57.0 \%) \\
\text { female }\end{array}$ & $\begin{array}{l}\text { January (20) } \\
\text { March (4) } \\
\text { June (6) } \\
\text { July (4) } \\
\text { September (8) } \\
\text { October (14) } \\
\text { November } \\
\text { (22) } \\
\text { December (8) }\end{array}$ & 45.3 & $\begin{array}{l}89,929 \\
(I Q R \\
33,999- \\
104,500)\end{array}$ \\
\hline $\begin{array}{l}\text { 14/NW/1460 } \\
\text { (Study 1) }\end{array}$ & $\begin{array}{l}\text { To define the } \\
\text { effect of } \\
\text { LAIV }^{3} \text { on } \\
\text { EHPC }^{4} \text {; study } \\
\text { control group } \\
\text { included in } \\
\text { this analysis } \\
\text { (started } \\
\text { 2016) }\end{array}$ & 62 & $\begin{array}{l}21 \\
\text { (IQR 19- } \\
22)\end{array}$ & $\begin{array}{l}32 \\
(51.6 \%) \\
\text { female }\end{array}$ & $\begin{array}{l}\text { January (19) } \\
\text { February (15) } \\
\text { March (6) } \\
\text { November } \\
\text { (22) }\end{array}$ & 38.7 & $\begin{array}{l}75,575 \\
\text { (IQR } \\
70,166- \\
81,499)\end{array}$ \\
\hline $\begin{array}{l}\text { 14/NW/1460 } \\
\text { (Study 2) }\end{array}$ & As study 1 & 163 & $\begin{array}{l}21 \\
\text { (IQR 19- } \\
22)\end{array}$ & $\begin{array}{l}89 \\
(54.6 \%) \\
\text { female }\end{array}$ & $\begin{array}{l}\text { January (35) } \\
\text { February (42) } \\
\text { March (22) } \\
\text { October (30) } \\
\text { November } \\
\text { (34) }\end{array}$ & 49.7 & $\begin{array}{l}81,249 \\
(I Q R \\
77,833- \\
85,333)\end{array}$ \\
\hline 15/NW/0146 & $\begin{array}{l}\text { Pilot study of } \\
\text { repeated } \\
\text { mucosal } \\
\text { sampling on } \\
\text { EHPC (started } \\
2015 \text { ) }\end{array}$ & 18 & $\begin{array}{l}28 \\
\text { (IQR 22- } \\
34)\end{array}$ & $\begin{array}{l}12 \\
(66.7 \%) \\
\text { female }\end{array}$ & $\begin{array}{l}\text { July (15) } \\
\text { August (3) }\end{array}$ & 38.9 & $\begin{array}{l}80,823 \\
\text { (IQR } \\
77,166- \\
84,333)\end{array}$ \\
\hline 12/NW/0873 & $\begin{array}{l}\text { To evaluate } \\
\text { the effect of } \\
\text { PCV5 on EHPC } \\
\text { compared to } \\
\text { Hepatitis A } \\
\text { vaccine; } \\
\text { study control } \\
\text { group } \\
\text { included in } \\
\text { this analysis } \\
\text { (started } \\
\text { 2013) }\end{array}$ & 45 & $\begin{array}{l}23 \\
\text { (IQR 19- } \\
23)\end{array}$ & $\begin{array}{l}28 \\
(62.2 \%) \\
\text { female }\end{array}$ & $\begin{array}{l}\text { February (3) } \\
\text { March (18) } \\
\text { May (9) } \\
\text { October (1) } \\
\text { November } \\
(14)\end{array}$ & 44.4 & $\begin{array}{l}82,938 \\
(I Q R \\
77,833- \\
88,583)\end{array}$ \\
\hline
\end{tabular}

\footnotetext{
${ }^{1}$ Serotype 6B pneumococcus

${ }^{2}$ Serotype $23 \mathrm{~F}$ pneumococcus

${ }^{3}$ Live Attenuated Influenza Vaccine

${ }^{4}$ Experimental Human Pneumococcal Carriage

${ }^{5}$ Pneumococcal Conjugate Vaccine
} 
medRxiv preprint doi: https://doi.org/10.1101/2021.10.04.21264228; this version posted October 5, 2021. The copyright holder for this preprint (which was not certified by peer review) is the author/funder, who has granted medRxiv a license to display the preprint in It is made available under a CC-BY-NC-ND 4.0 International license .

\section{Pooled Data}

\begin{tabular}{|c|c|c|c|c|c|c|}
\hline All (pooled) & 374 & $\begin{array}{l}22 \\
\text { (IQR 19- } \\
22)\end{array}$ & $\begin{array}{l}210 \\
(56.2 \%) \\
\text { female }\end{array}$ & $\begin{array}{l}\text { January (74) } \\
\text { February (60) } \\
\text { March (50) } \\
\text { May (9) } \\
\text { June (6) } \\
\text { July (19) } \\
\text { August (3) } \\
\text { September (8) } \\
\text { October (45) } \\
\text { November } \\
\text { (92) } \\
\text { December (8) }\end{array}$ & 45.7 & $\begin{array}{l}82,502 \\
\text { (IQR } \\
74,333- \\
85,333)\end{array}$ \\
\hline
\end{tabular}


medRxiv preprint doi: https://doi.org/10.1101/2021.10.04.21264228; this version posted October 5, 2021. The copyright holder for this preprint (which was not certified by peer review) is the author/funder, who has granted medRxiv a license to display the preprint in

It is made available under a CC-BY-NC-ND 4.0 International license .
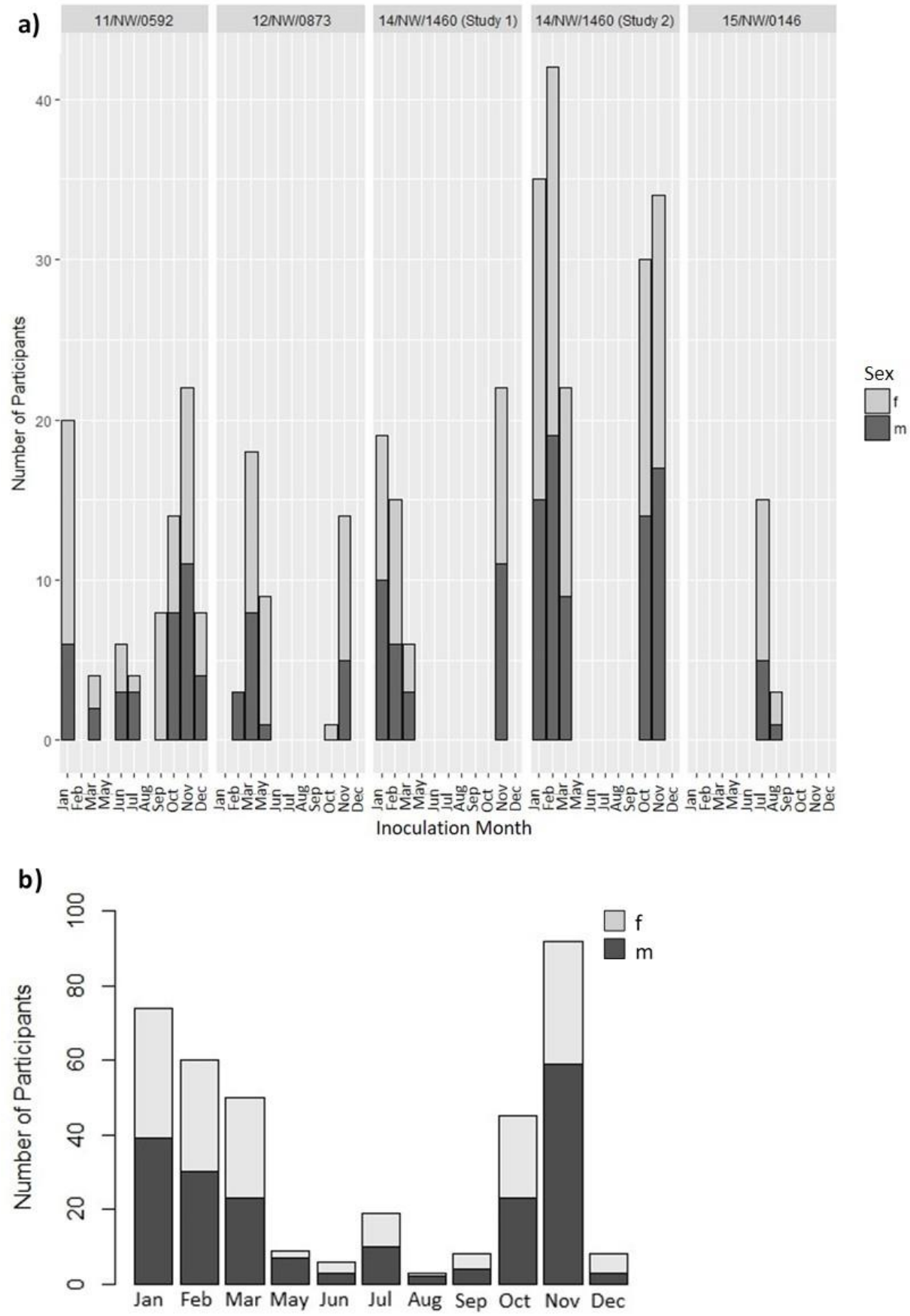

Inoculation Month

Figure 1: a) Bar plots showing distribution of data across months of the year for each study ( $m=$ male, grey, $f=$ female, black). b) Distribution of data across months of the year for the pooled cohort ( $m=$ male, $f=f e m a l e)$. No volunteers were inoculated during the month of April in any study.

Male sex associates with decreased susceptibility to pneumococcal carriage acquisition.

First, we assessed whether time of the year was associated with carriage acquisition rates (Figure 2a). May, August and November had the lowest proportion of carriage of all months, below the overall average of $45.7 \%$ (22.2\%, 33.3\% and 35.9\%, respectively) whilst December and March had the highest ( $62.5 \%$ and $54.0 \%$, respectively). Carriage acquisition rates for remaining months ranged from $47.3-50.0 \%$. Logistic regression analysis using a generalised 
medRxiv preprint doi: https://doi.org/10.1101/2021.10.04.21264228; this version posted October 5, 2021. The copyright holder for this preprint (which was not certified by peer review) is the author/funder, who has granted medRxiv a license to display the preprint in It is made available under a CC-BY-NC-ND 4.0 International license.

linear model found no specific inoculation month was significantly associated with carriage acquisition. However, the sample sizes for the months April through September and December were small (Table 1, Figure 1, Figure 2a). As for inoculation month, age category did not significantly associate with carriage acquisition rates, although there was a lack of data for ages over 30 (Table 1, Figure 2b). Of the 210 female volunteers, 107 (51.0\%) became colonised whereas, of the 164 male volunteers, 64 (39.0\%) became colonised (Figures $2 \mathrm{c}$ and $2 \mathrm{~d}$ ). The number of males who became carriers following inoculation was significantly lower than the number of women who became colonised (Fisher's exact test OR, 0.61; 95\% Cl, 0.41-0.93; $p=0.03$ ).

a)

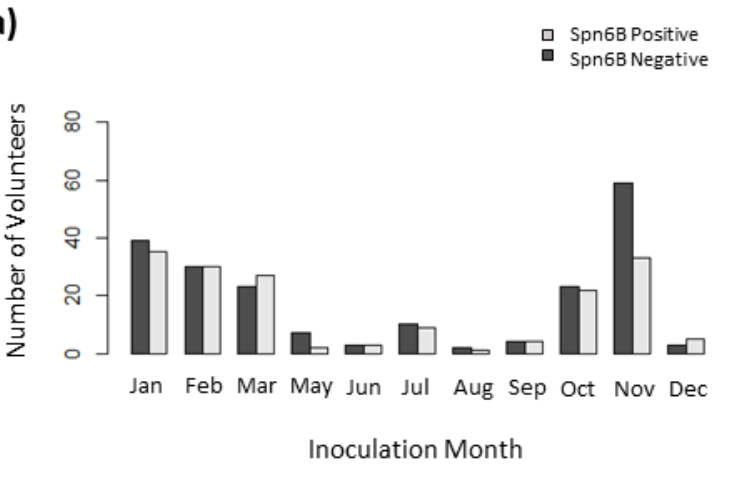

c)

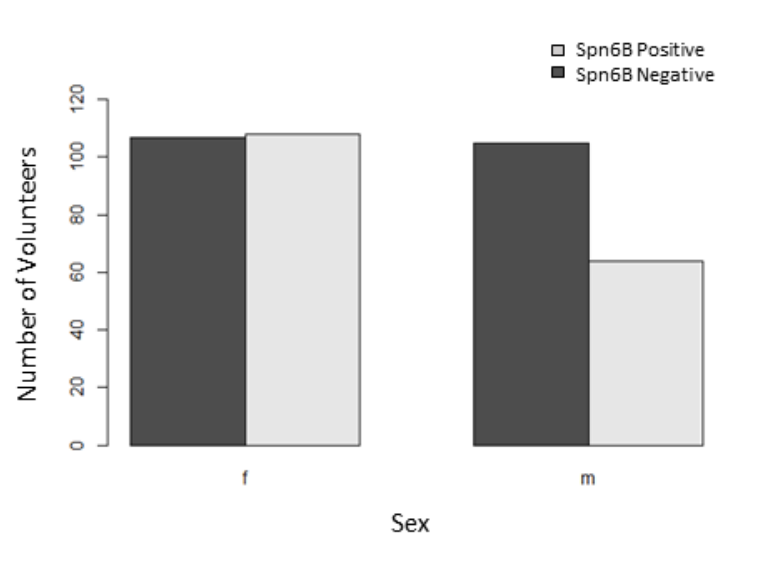

b)

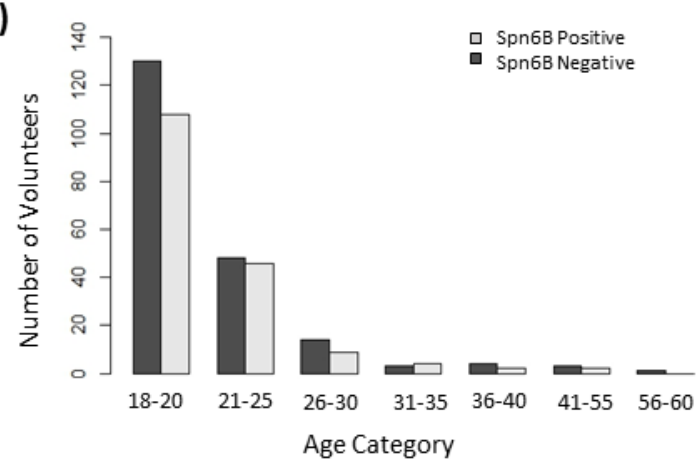

d)

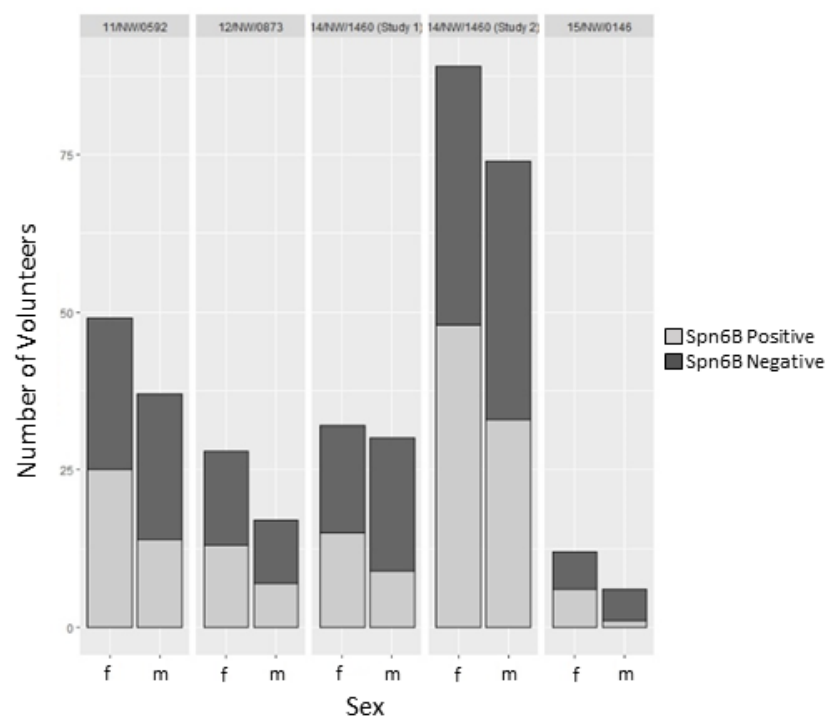

Figure 2: a) The number of carriage positive (grey) and carriage negative (black) volunteers in each inoculation month. b) The number of carriage positive and carriage negative volunteers in each age category. c) The number of female ( $\mathrm{f}$ ) and male $(\mathrm{m})$ volunteers in the pooled dataset with positive (grey) and negative (black) pneumococcal carriage status. d) The number of female (f) and male ( $m$ ) volunteers in each study with positive (grey) and negative (black) pneumococcal carriage status.

Time taken to establish experimental carriage following nasal inoculation is not affected by season, age or sex.

Notably, in $87.1 \%$ of the 171 volunteers who established carriage, colonisation was detected for the first time at the first sampling point following inoculation (day 2) (Figure 3) as compared to $10.5 \%$ at the second sampling point (day 6,7 or 9 ) and $1.2 \%$ at the third and fourth sampling points (day 14 and day 27, respectively). Sex, age and inoculation month 
medRxiv preprint doi: https://doi.org/10.1101/2021.10.04.21264228; this version posted October 5, 2021. The copyright holder for this preprint (which was not certified by peer review) is the author/funder, who has granted medRxiv a license to display the preprint in It is made available under a CC-BY-NC-ND 4.0 International license .

had no obvious effect on the day that carriage was first detected (Figure 3).

a)

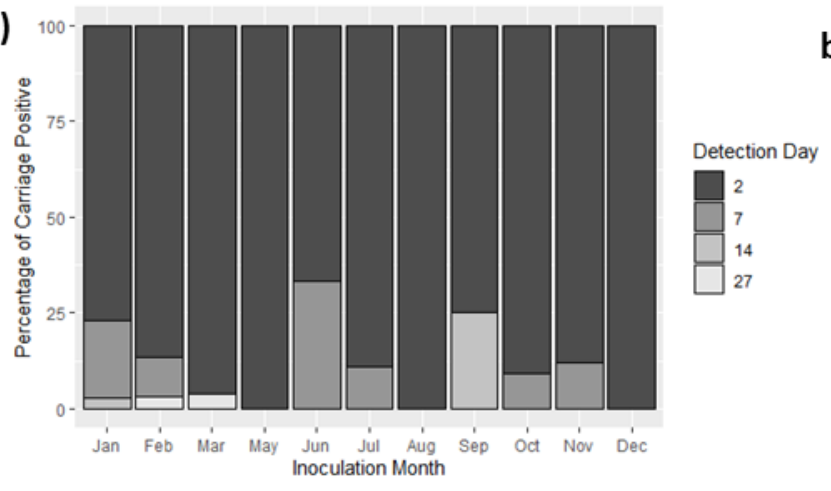

c)

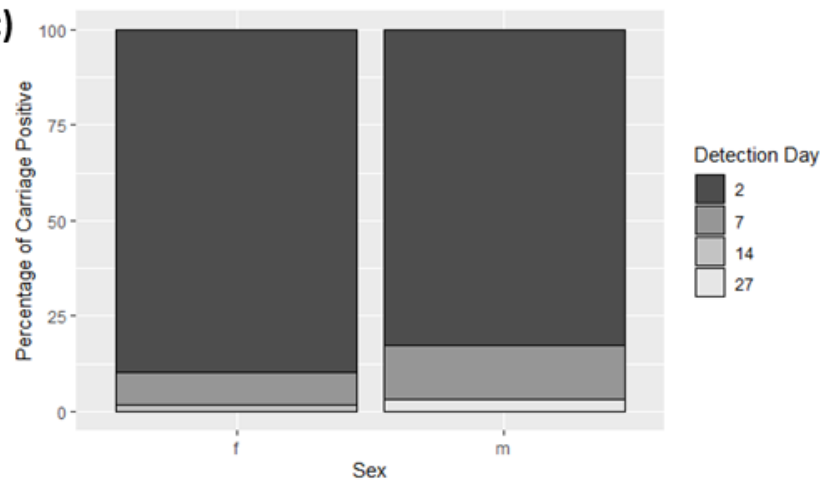

b)

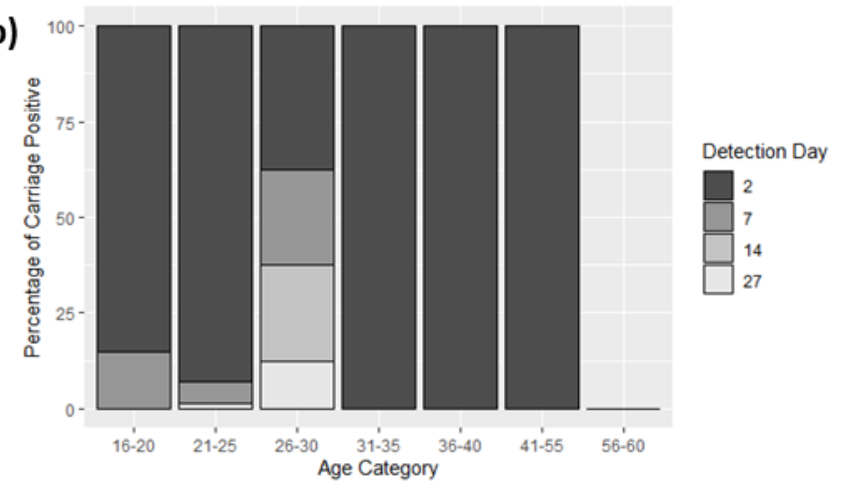

Figure 3: Percentage of carriage positive volunteers on which pneumococcal carriage was first detected 2 (black), 6, 7 or 9 (dark grey), 14 (light grey) or 27 (white) days after initial inoculation across each inoculation month (a), each age category (b) and in females and males (c).

\section{Statistical analysis and Generalised Linear Mixed Effects (GLME) model}

To understand the impact of environmental variables, we then used a GLME model to assess the strength of association of age, gender, temperature, rainfall and air quality with carriage acquisition (Table 2 ).

Table 2: Log Odds, standard error values and $p$-values obtained from the generalised linear mixed-effects model.

\begin{tabular}{llll}
\hline & $\begin{array}{l}\text { Logit } \\
\text { Coefficient } \\
\text { (Log Odds) }\end{array}$ & $\begin{array}{l}\text { Standard } \\
\text { Error } \\
\text { (SE) }\end{array}$ & -value \\
\hline Sex (male) & -0.502 & 0.214 & 0.019 \\
\hline${\text { PM } 2.5^{1}}^{\text {Minimum }}$ & -0.248 & 0.128 & 0.052 \\
\hline $\begin{array}{l}\text { temperature } \\
\text { Rainfall }\end{array}$ & -0.239 & 0.118 & 0.043 \\
\hline
\end{tabular}

\footnotetext{
${ }^{1}$ Particulate matter $<2.5 \mu \mathrm{m}$ in diameter
} 
medRxiv preprint doi: https://doi.org/10.1101/2021.10.04.21264228; this version posted October 5, 2021. The copyright holder for this preprint (which was not certified by peer review) is the author/funder, who has granted medRxiv a license to display the preprint in It is made available under a CC-BY-NC-ND 4.0 International license .

Results from the GLME model found that males were significantly less likely to be colonised with pneumococcus than were females (OR, 0.61;95\% Cl, 0.40-0.92; $p=0.02)$. Moreover, increased minimum temperature $(\mathrm{OR}, 0.79 ; 95 \% \mathrm{Cl}, 0.63-0.99 ; p=0.04)$ was significantly associated with decreased likelihood of carriage acquisition rates. Although not significant, $\mathrm{PM}_{2.5}$ was also correlated with decreased odds of carriage acquisition $(\mathrm{OR}, 0.78 ; 95 \% \mathrm{Cl}$, $0.61-1.00 ; p=0.05)$, as was rainfall (OR, 0.84; 95\% Cl, 0.67-1.05; $p=0.12)$. The Akaike information criterion (AIC) of the model increased when these variables were removed, suggesting a potential link with colonisation.

As would be expected, there was collinearity between $\mathrm{PM}_{2.5}$, minimum temperature and rainfall (Table 3). Thus, the standard errors of parameter coefficient estimates are likely greater than they would be if the parameters were not correlated.

Table 3: Correlation matrix for variables included in GLME model.

\begin{tabular}{llll}
\hline & PM2.5 & $\begin{array}{l}\text { Minimum } \\
\text { Temperature }\end{array}$ & Rainfall \\
\hline PM2.5 $^{1}$ & 1 & 0.44 & 0.36 \\
\hline $\begin{array}{l}\text { Minimum } \\
\text { Temperature }\end{array}$ & 0.44 & 1 & 0.11 \\
\hline Rainfall & 0.36 & 0.11 & 1 \\
\hline
\end{tabular}

The intraclass correlation (ICC) showed study grouping did not account for any residual variance in the model $(I C C=0.00 \%)$.

\section{Discussion}

We associated subject sex and climatic variables with outcome following experimental human challenge studies conducted between 2011 and 2017, including 374 volunteers. The multivariate analysis conducted in this study found that male sex is significantly associated with reduced odds of establishing pneumococcal carriage. Increases in minimum temperature were significantly associated with decreased rates of colonisation, thus odds of colonisation were significantly increased with cooler temperatures, concurring with findings of previous studies $[7,13,14]$. Increased $\mathrm{PM}_{2.5}$ was inversely correlated with pneumococcal carriage acquisition, although this was not significant. Similarly, although not significantly, odds of colonisation were found to be at least weakly inversely correlated with increased rainfall, corresponding to previous results [8]. Additional environmental variables for which data were obtained were not found to improve model fit. Nor did the inclusion of age category. The positively skewed age distribution limited our power to detect differences in pneumococcal carriage acquisition between the younger and older volunteers. Across all the clinical trials included in this analysis, volunteer cohorts were predominantly university students, which explains the paucity of data for volunteers over 30 years of age and for months when students are away from university (April through September for Easter and Summer holidays and December for Winter holiday).

\footnotetext{
${ }^{1}$ Particulate matter $<2.5 \mu \mathrm{m}$ in diameter
} 
medRxiv preprint doi: https://doi.org/10.1101/2021.10.04.21264228; this version posted October 5, 2021. The copyright holder for this preprint (which was not certified by peer review) is the author/funder, who has granted medRxiv a license to display the preprint in It is made available under a CC-BY-NC-ND 4.0 International license.

The finding in our study that males had significantly lower likelihood of pneumococcal carriage acquisition than females is supported by previous studies showing that females are more susceptible than males to infections of the upper respiratory tract whereas, males are more susceptible to lower respiratory tract infections [15]. Nevertheless, the results of this study differ from previous analyses, which have found that male sex is significantly associated with increased odds of nasopharyngeal pneumococcal carriage $[16,17]$ or that there is no significant difference in the prevalence of carriage between sexes [13]. A potential explanation for this discrepancy is that previous studies analysing sex-linked odds of carriage have included participants under the age of 18 , whereas our study included adults over 18 years of age only. It is unlikely that there are differences in the sex-linked odds of carriage in children, whereas adults and adolescents will exhibit hormone effects on the immune system. These have been recently reviewed in the lung, with androgens generally considered anti-inflammatory and oestrogens pro-inflammatory [18] in the context of chronic lung disease. The delicate balance that determines mucosal immunity in response to acute challenge will differ from that in chronic inflammation and is a focus of our group's work [19]. Furthermore, our study uses a controlled model of infection, with important variables including geographical location controlled. Previous studies considered natural carriage of various serotypes within various populations in countries such as Brazil and sub-Saharan Africa where social factors have different effects on interaction, contact and social crowding. Using a controlled model of infection thereby enables us to determine propensity of colonisation based on sex while controlling for other variables which may interfere with this finding.

We observed that increased $\mathrm{PM}_{2.5}$ concentration associated with a decreased likelihood of carriage acquisition. This is not counter-intuitive and has been shown in a mouse model [20]. The mucosal defence against pneumococcus is dependent on neutrophil activation and smoke potentially activates neutrophils in the mucosa. It has been well established that fine and ultrafine particulates are detrimental to lung and cardiovascular health, both in the long and short-term, increasing morbidity and mortality [21-24] by a cytokine based proinflammatory mechanism. The burden of pneumococcal infection, particularly in the elderly, is worsened following exposure to ambient $\mathrm{PM}_{2.5}$ and exposure to $\mathrm{PM}$ may increase pneumonia-related mortality by supressing immune functions such as macrophage responsiveness $[9,25]$. Coarse particulates $(>8 \mu \mathrm{m})$ have greater impact on the upper respiratory tract, depositing in the pharynx, larynx and trachea in a size-dependent manner, whilst fine particulates $(<1-3 \mu \mathrm{m})$ penetrate lung tissue and deposit in the alveoli $[26,27]$. When air pollution particles interact with alveolar macrophages, phagocytosis, release of inflammatory mediators and oxidant production is triggered [28]. However, alveolar macrophage function, particularly phagocytosis of pneumococci and mycobacteria, is impaired by increased exposure to particulates [19]. Interestingly, although internalisation and phagocytosis decreases, alveolar macrophage binding to pneumococcus has been shown to be enhanced by $\mathrm{PM}_{2.5}$ [28]. The effect of exposure to PM on the nasal mucosa has been less well documented, although some murine and human studies have demonstrated that exposure to particulates induces recruitment of immune cells to the nasal mucosa, promoting inflammation [29-32]. Thus, it is conceivable that increased inflammation related to higher levels of $\mathrm{PM}_{2.5}$ led to a transient state of protection against carriage acquisition. 
medRxiv preprint doi: https://doi.org/10.1101/2021.10.04.21264228; this version posted October 5,2021 . The copyright holder for this preprint (which was not certified by peer review) is the author/funder, who has granted medRxiv a license to display the preprint in It is made available under a CC-BY-NC-ND 4.0 International license.

Notably, preliminary data has shown that increased exposure to air pollution promotes expression of PAF receptors in the nasal epithelium, and thus it might be expected that this would enhance pneumococcal binding to the nasal epithelium and subsequent carriage [33]. On the other hand, increased exposure of the nasal epithelium to $\mathrm{PM}_{2.5}$ stimulates increased IL-8 production [34]. IL-8 is a pro-inflammatory chemoattractant and promotes the recruitment of neutrophils to the nasal mucosa, which play an important role in pneumococcal clearance [35]. Thus, it could be postulated that in this way pneumococcal carriage is inhibited.

Mice models of nasopharyngeal carriage of pneumococcus have exhibited significantly increased pneumococcal density in the nasopharynx following exposure to dust (representative of particulates $<10 \mu \mathrm{m}$ ) compared to normal bacterial colonised control mice. In addition, exposure to dust triggered local inflammation in the nasopharynx and promoted a more invasive pneumococcal phenotype [36]. Dust exposure also resulted in significantly reduced phagocyte-mediated bacterial killing. Similarly, a 2017 study showed that in murine models of nasopharyngeal colonisation, black carbon, a major component of PM, promoted the spread of pneumococcus from the nasopharynx to the lungs [37]. However, the same degree of colonisation was observed in the upper respiratory tracts of mice exposed to both black carbon and pneumococcus and those infected with pneumococcus only. Interestingly, black carbon was found to induce a biological effect on non-capsulated pneumococcus resulting in a change in biofilm structure. In contrast, our study found that $\mathrm{PM}_{2.5}$ elicited a protective effect against nasopharyngeal pneumococcal colonisation. Markedly, ours is the first study to model the effects of ambient PM on experimental pneumococcal carriage in humans. Similarly, previous univariate analysis found that PM was associated with reduced rates of pneumococcal infection [10]. Whilst no definitive explanation may be offered at this point, as to why $\mathrm{PM}_{2.5}$ might impair colonisation, it could be hypothesised that the presence of particulates might prevent bacteria from establishing colonisation due to the enhanced presence of pro-inflammatory cells in the nasopharynx. Furthermore, it is important to consider that that the chemical composition of PM could alter its biological effects and thus location is an important factor [21, 38-40].

Although measures were taken to limit the inclusion of collinear variables in the model, this does not allow dissection of the independent effects. Unknown confounders, for example concomitant respiratory viral infections, are likely to play are part in these complex relationships. The scope of work was limited by the range of data elements incorporated into previous studies. While we excluded smokers from the study, for example, we have no information on exposure to second-hand smoke. Our analysis at aggregate environmental data was also limited in resolution. Nevertheless, volunteer cohorts were relatively homogeneous by occupation, general health status, non-smoking status, and inoculum dose which gives confidence in the internal consistency of our findings.

In conclusion, this study found that males are significantly less likely than females to be colonised in the nasopharynx following experimental challenge with serotype 6B pneumococcus. Furthermore, nasopharyngeal pneumococcal carriage acquisition was found 
medRxiv preprint doi: https://doi.org/10.1101/2021.10.04.21264228; this version posted October 5,2021 . The copyright holder for this

preprint (which was not certified by peer review) is the author/funder, who has granted medRxiv a license to display the preprint in It is made available under a CC-BY-NC-ND 4.0 International license.

to be positively correlated with cooler temperatures, decreased levels of $\mathrm{PM}_{2.5}$ in the environment and higher rainfall. Further studies and analysis are needed to better ascertain correlation of pneumococcal acquisition with environmental factors in order to establish how the environment, particularly air quality, could affect likelihood of pneumococcal carriage acquisition in the community. Further work is being conducted to establish how sex might alter immunological responses to pneumococcus.

\section{Acknowledgements}

KSC is funded by the MRC Doctoral Training Partnership. DMF, AMC, SBG, SPJ, JR, CS, BU and KSC are members of the Human Infection Challenge Network for Vaccine Development (HICVac), which is funded by the GCRF Networks in Vaccines Research and Development, which was co-funded by the MRC and BBSRC. The challenge studies were funded by the MRC (grant MR/M011569/1) awarded to SBG and DMF and the Bill and Melinda Gates Foundation (grant OPP1117728) awarded to DMF. We would like to acknowledge Dr Helen Hill, Sister Angela Hyder-Wright, Dr Jenna Gritzfeld, Dr Hugh Adler, Dr Seher Zaidi and Dr Victoria Connor for their contribution to the EHPC trials referred to in this work.

\section{References}

1. Weiser JN, Ferreira DM, Paton JC. Streptococcus pneumoniae: transmission, colonization and invasion. Nat Rev Microbiol. 2018; 16: 355-367.

2. Abdullahi O, Karani A, Tigoi CC, et al. The prevalence and risk factors for pneumococcal colonization of the nasopharynx among children in Kilifi District, Kenya. PLoS One. 2012; 7: e30787.

3. Goldblatt $D$, Hussain $M$, Andrews $N$, et al. Antibody Responses to Nasopharyngeal Carriage of Streptococcus pneumoniae in Adults: A Longitudinal Household Study. J. Infect. Dis. 2005; 192: 387-393.

4. Welte $T$, Torres A, Nathwani D. Clinical and economic burden of community-acquired pneumonia among adults in Europe. Thorax 2012; 67: 71-79.

5. Walden AP, Clarke GM, McKechnie S, et al. Patients with community acquired pneumonia admitted to European intensive care units: an epidemiological survey of the GenOSept cohort. Crit. Care 2014; 18: R58.

6. UNICEF. Pneumonia. https://data.unicef.org/topic/child-health/pneumonia/ Date last updated: November 2019. Date last accessed: March $9^{\text {th }} 2020$.

7. Kim PE, Musher DM, Glezen WP, et al. Association of invasive pneumococcal disease with season, atmospheric conditions, air pollution, and the isolation of respiratory viruses. Clin. Infect. Dis. 1996; 22: 100-106. 
medRxiv preprint doi: https://doi.org/10.1101/2021.10.04.21264228; this version posted October 5, 2021. The copyright holder for this

preprint (which was not certified by peer review) is the author/funder, who has granted medRxiv a license to display the preprint in It is made available under a CC-BY-NC-ND 4.0 International license .

8. Numminen $\mathrm{E}$, Chewapreecha $\mathrm{C}$, Turner $\mathrm{C}$, et al. Climate induces seasonality in pneumococcal transmission. Sci. Rep. 2015; 5: 11344.

9. Vodonos A, Kloog I, Boehm L, et al. The impact of exposure to particulate air pollution from non-anthropogenic sources on hospital admissions due to pneumonia. Eur. Respir. J. 2016.

10. Sahuquillo-Arce JM, Ibáñez-Martínez E, Hernández-Cabezas A, et al. Influence of environmental conditions and pollution on the incidence of Streptococcus pneumoniae infections. ERJ Open Res. 2017; 3: 14.

11. Ferreira DM, Neill DR, Bangert $M$, et al. Controlled human infection and rechallenge with Streptococcus pneumoniae reveals the protective efficacy of carriage in healthy adults. Am J Respir Crit Care Med. 2013; 187(8): 855-64. Erratum in: Am J Respir Crit Care Med. 2013; 187(10): 1153. Bricio Moreno, Laura [corrected to Bricio-Moreno, Laura].

12. Becker RA, Chambers JM, Wilks AR. The New S Language. Wandsworth \& Brooks/Cole 1988.

13. Usuf E, Bottomley C, Adegbola RA, et al. Pneumococcal carriage in sub-Saharan Africa--a systematic review. PLoS One. 2014; 9: e85001.

14. Dowell SF, Whitney CG, Wright C, et al. Seasonal patterns of invasive pneumococcal disease. Emerg. Infect. Dis. 2003; 9: 574-579.

15. Falagas ME, Mourtzoukou EG, Vardakas KZ. Sex differences in the incidence and severity of respiratory tract infections. Respir Med. 2007; 101: 1845-1865.

16. Cardozo DM, Nascimento-Carvalho CM, Andrade AL, et al. Prevalence and risk factors for nasopharyngeal carriage of Streptococcus pneumoniae among adolescents. J Med Microbiol. 2008; 57: 185-189.

17. Adetifa IMO, Adamu AL, Karani A, et al. Nasopharyngeal Pneumococcal Carriage in Nigeria: a two-site, population-based survey. Scientific Reports 2018; 8: 3509.

18. Reyes-García J, Montaño LM, Carbajal-García A, et al. Sex Hormones and Lung Inflammation. In: Wang YX. (eds) Lung Inflammation in Health and Disease, Volume II. Advances in Experimental Medicine and Biology, vol 1304. Springer, Cham. 2021.

19. Rylance J, Fullerton DG, Scriven J, et al. Household air pollution causes dose-dependent inflammation and altered phagocytosis in human macrophages. Am. J. Respir. Cell Mol. Biol. 2015; 52: 584-593. 
medRxiv preprint doi: https://doi.org/10.1101/2021.10.04.21264228; this version posted October 5, 2021. The copyright holder for this preprint (which was not certified by peer review) is the author/funder, who has granted medRxiv a license to display the preprint in It is made available under a CC-BY-NC-ND 4.0 International license .

20. Tellabati A, Fernandes VE, Teichert F et al. Acute exposure of mice to high-dose ultrafine carbon black decreases susceptibility to pneumococcal pneumonia. Part Fibre Toxicol 2010; 7, 30.

21. Seaton, A, Godden D, MacNee W, Donaldson K. Particulate air pollution and acute health effects. The Lancet 1995; 345: 176-178.

22. Atkinson RW, Anderson HR, Sunyer J, et al. Acute effects of particulate air pollution on respiratory admissions: Results from APHEA 2 project. Am. J. Respir. Crit. Care Med. 2001; 164: 1860-1866.

23. Pope CA, Burnett RT, Thun MJ, et al. Lung cancer, cardiopulmonary mortality, and longterm exposure to fine particulate air pollution. JAMA. 2002; 287: 1132-1141.

24. Valavanidis A, Fiotakis K, Vlachogianni T. Airborne particulate matter and human health: Toxicological assessment and importance of size and composition of particles for oxidative damage and carcinogenic mechanisms. J. Environ. Sci. Heal. - Part C Environ. Carcinog. Ecotoxicol. Rev. 2008; 26: 339-362.

25. Zelikoff JT, Chen LC, Cohen MD, et al. Effects of inhaled ambient particulate matter on pulmonary antimicrobial immune defense. Inhal Toxicol 2003; 15: 131-150.

26. D'Amato G. Effects of climatic changes and urban air pollution on the rising trends of respiratory allergy and asthma. Multidiscip Respir Med. 2011; 6: 28-37.

27. Brown JS, Gordon T, Price O, et al. Thoracic and respirable particle definitions for human health risk assessment. Part Fibre Toxicol. 2013; 10: 12.

28. Zhou H, Kobzik L. Effect of concentrated ambient particles on macrophage phagocytosis and killing of Streptococcus pneumoniae. Am. J. Respir. Cell Mol. Biol. 2007; 36: 460-465

29. Diaz-Sanchez D, Garcia MP, Wang M, et al. Nasal challenge with diesel exhaust particles can induce sensitization to a neoallergen in the human mucosa. J. Allergy Clin. Immunol. 1999; 104: 1183-1188.

30. Yoshizaki K, Brito JM, Toledo AC, et al. Subchronic effects of nasally instilled diesel exhaust particulates on the nasal and airway epithelia in mice. Inhal. Toxicol. 2010; 22: 610-617.

31. Shen $\mathrm{Y}$, Zhang ZH, Hu D, et al. The airway inflammation induced by nasal inoculation of PM2.5 and the treatment of bacterial lysates in rats. Sci. Rep. 2018; 8: 9816

32. Wu W, Jin Y, Carlsten C. Inflammatory health effects of indoor and outdoor particulate matter. J. Allergy Clin. Immunol. 2018; 141: 833-844. 
medRxiv preprint doi: https://doi.org/10.1101/2021.10.04.21264228; this version posted October 5, 2021. The copyright holder for this

preprint (which was not certified by peer review) is the author/funder, who has granted medRxiv a license to display the preprint in It is made available under a CC-BY-NC-ND 4.0 International license .

33. Miyashita L, Padovan M, Suri R, et al. Expression of Nasal Epithelial Platelet Activating Factor Receptor (PAFR) and in vivo Exposure to Air Pollution Journal of Allergy and Clinical Immunology 2017; 139(2), AB264.

34. Xian M, Ma S, Wang K, et al. Particulate Matter 2.5 Causes Deficiency in Barrier Integrity in Human Nasal Epithelial Cells. Allergy Asthma Immunol Res. 2020; 12(1): 56-71.

35. Jochems SP, de Ruiter K, Solórzano $\mathrm{C}$, et al. Innate and adaptive nasal mucosal immune responses following experimental human pneumococcal colonization. J Clin Invest. 2019; 130(10): 4523-4538.

36. Jusot JF, Neill DR, Waters EM, et al. Airborne dust and high temperatures are risk factors for invasive bacterial disease. J. Allergy Clin. Immunol. 2017; 139: 977-986.

37. Hussey SJK, Purves J, Allcock N, et al. Air pollution alters Staphylococcus aureus and Streptococcus pneumoniae biofilms, antibiotic tolerance and colonisation. Environ. Microbiol. 2017; 19: 1868-1880.

38. Adams K, Greenbaum DS, Shaikh R, et al. Particulate matter components, sources, and health: Systematic approaches to testing effects. J. Air Waste Manag. Assoc. 2015; 65: 544-558.

39. Dominici F, Wang Y, Correia AW, et al. Chemical Composition of Fine Particulate Matter and Life Expectancy: In 95 US Counties between 2002 and 2007. Epidemiology 2015; 26: 556-564.

40. Ferreira TM, Forti MC, de Freitas CU, et al. Effects of particulate matter and its chemical constituents on elderly hospital admissions due to circulatory and respiratory diseases. Int. J. Environ. Res. Public Health 2016; 13: 947. 
medRxiv preprint doi: https://doi.org/10.1101/2021.10.04.21264228; this version posted October 5, 2021. The copyright holder for this preprint (which was not certified by peer review) is the author/funder, who has granted medRxiv a license to display the preprint in It is made available under a CC-BY-NC-ND 4.0 International license.
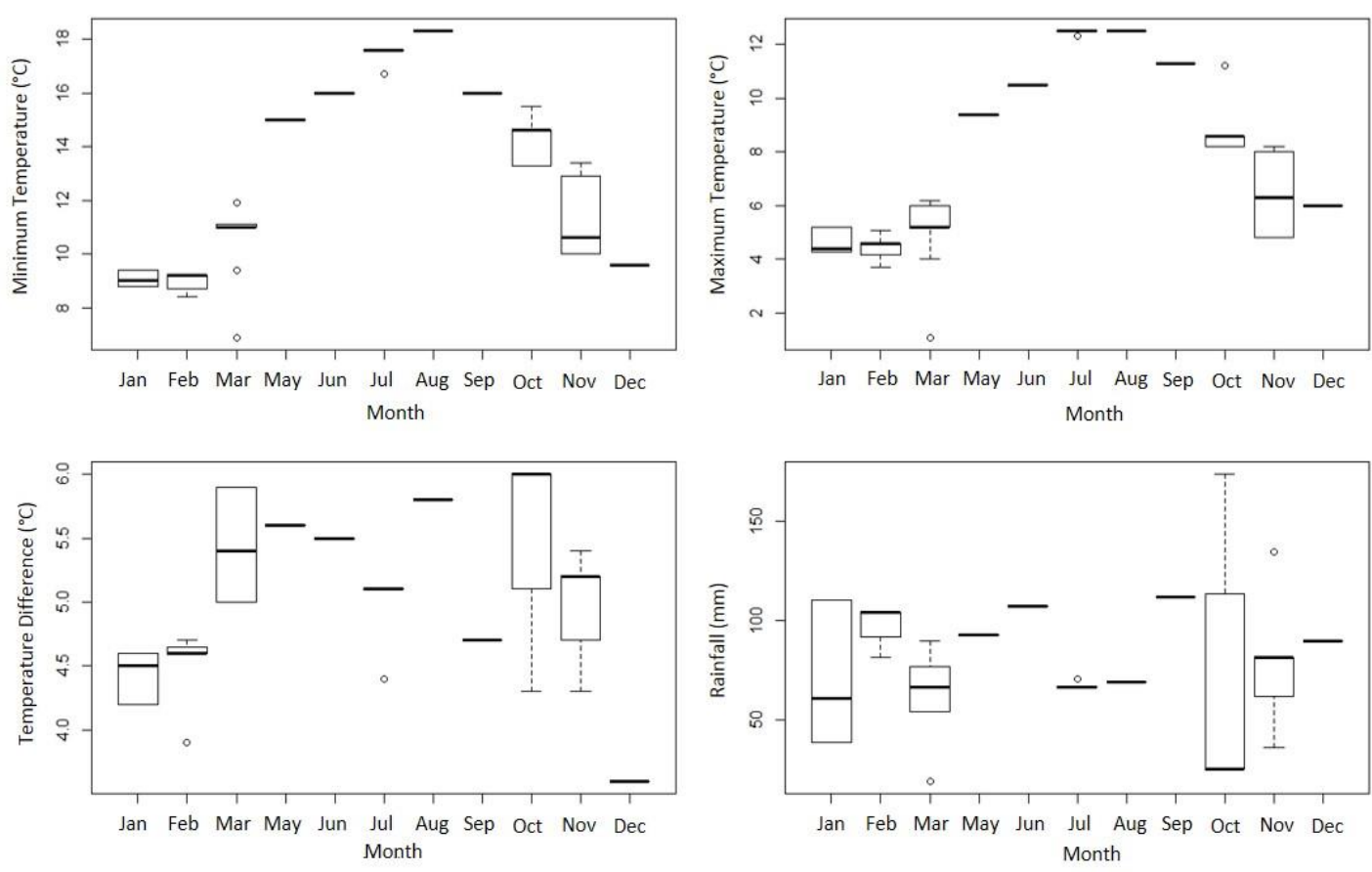

$$
\begin{aligned}
& \text { Jan Feb Mar May Jun Jul Aug Sep Oct Nov Dec } \\
& \text { Month }
\end{aligned}
$$

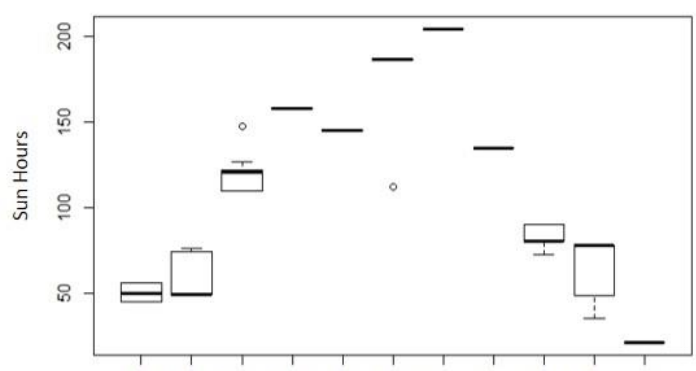

Jan Feb Mar May Jun Jul Aug Sep Oct Nov Dec

Month

Supplementary Figure 1: Aggregated monthly average minimum temperature $\left({ }^{\circ} \mathrm{C}\right)$, maximum temperature $\left({ }^{\circ} \mathrm{C}\right)$, temperature difference $\left({ }^{\circ} \mathrm{C}\right.$ ), rainfall $(\mathrm{mm})$ and sun hours from November 2011 to March 2017 (excluding month of April). Data obtained from the Met Office Valley, Anglesey monitoring site. 
medRxiv preprint doi: https://doi.org/10.1101/2021.10.04.21264228; this version posted October 5, 2021. The copyright holder for this preprint (which was not certified by peer review) is the author/funder, who has granted medRxiv a license to display the preprint in It is made available under a CC-BY-NC-ND 4.0 International license

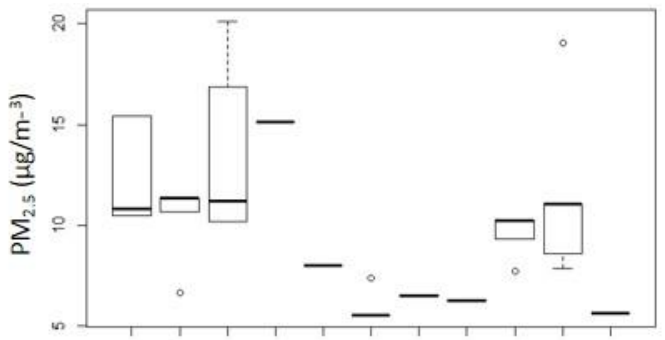

Jan Feb Mar May Jun Jul Aug Sep Oct Nov Dec Month

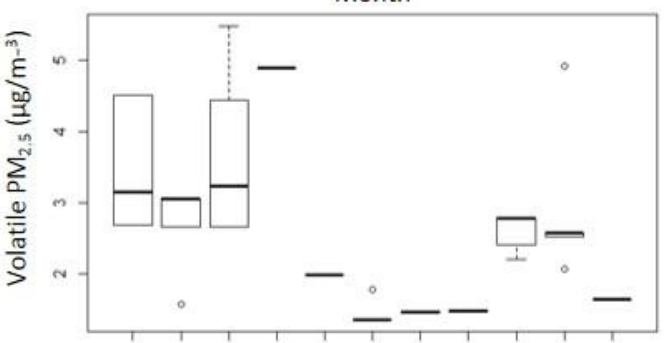

Jan Feb Mar May Jun Jul Aug Sep Oct Nov Dec Month

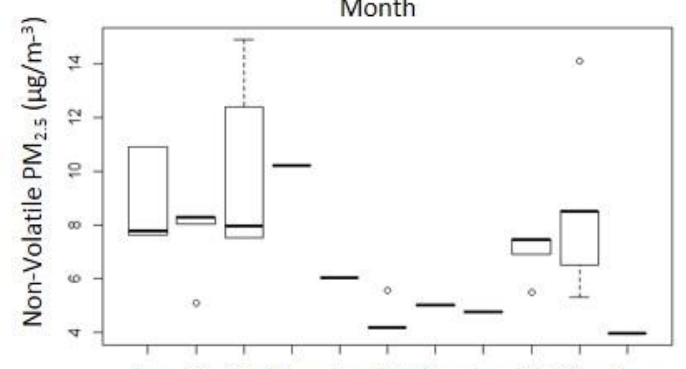

Jan Feb Mar May Jun Jul Aug Sep Oct Nov Dec Month

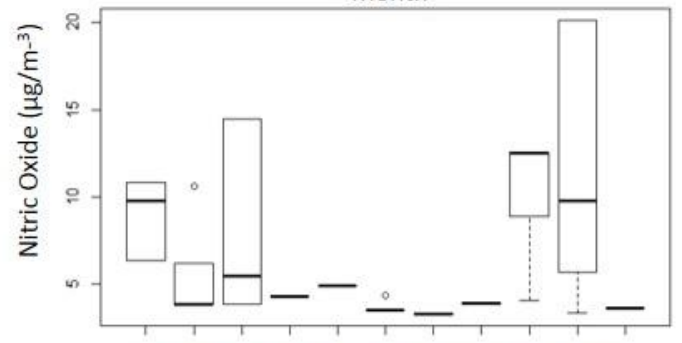

Jan Feb Mar May Jun Jul Aug Sep Oct Nov Dec Month

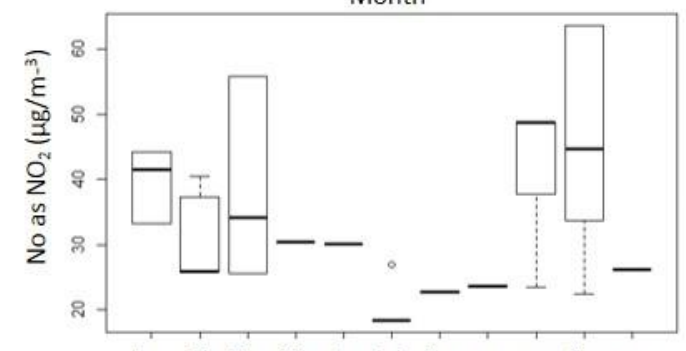

Jan Feb Mar May Jun Jul Aug Sep Oct Nov Dec Month

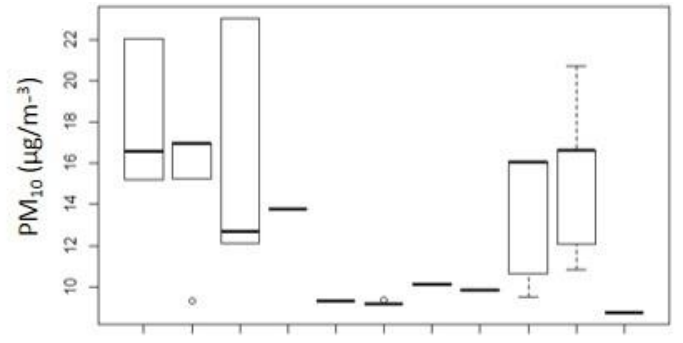

Jan Feb Mar May Jun Jul Aug Sep Oct Nov Dec Month

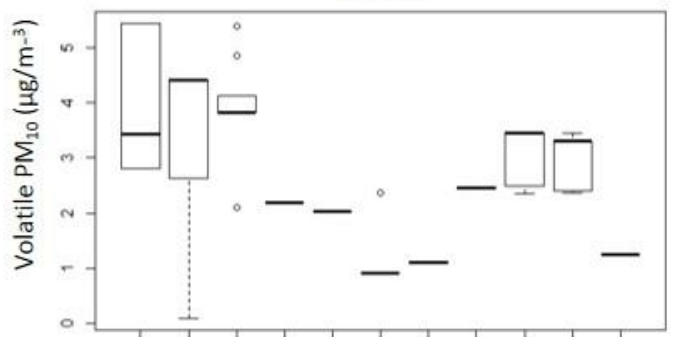

Jan Feb Mar May Jun Jul Aug Sep Oct Nov Dec Month

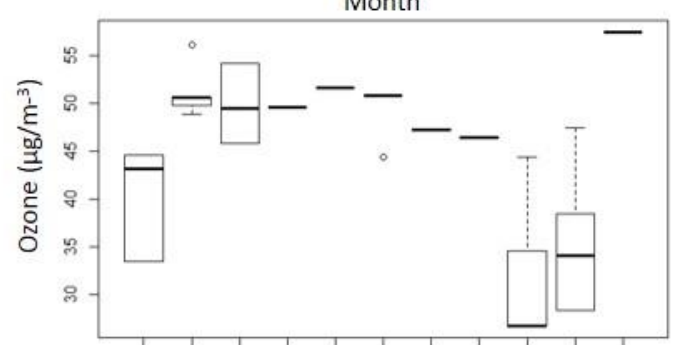

Jan Feb Mar May Jun Jul Aug Sep Oct Nov Dec Month

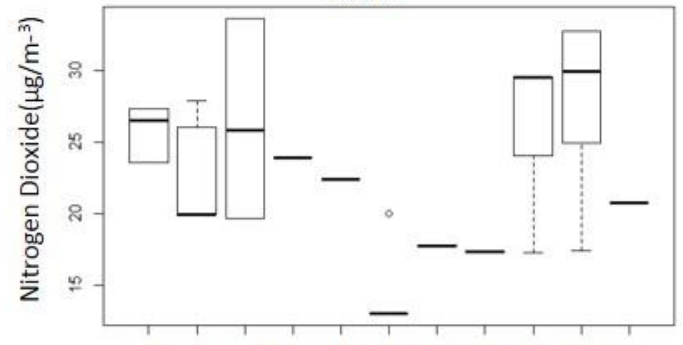

Jan Feb Mar May Jun Jul Aug Sep Oct Nov Dec Month

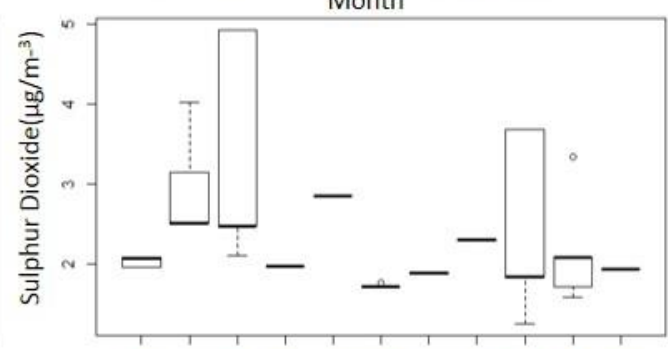

Jan Feb Mar May Jun Jul Aug Sep Oct Nov Dec Month

Supplementary Figure 2: Aggregated monthly average $\left(\mu \mathrm{g} / \mathrm{m}^{-3}\right) \mathrm{PM}_{2.5}$ and $\mathrm{PM}_{10}$, volatile and non-volatile $\mathrm{PM}_{2.5}$, volatile $\mathrm{PM}_{10}$, ozone, $\mathrm{NO}, \mathrm{NO}_{2}, \mathrm{NO}$ as $\mathrm{NO}_{2}$ and $\mathrm{SO}_{2}$ from November 2011 to March 2017 (excluding month of April). Data obtained from DEFRA Speke, Liverpool monitoring site. 
medRxiv preprint doi: https://doi.org/10.1101/2021.10.04.21264228; this version posted October 5, 2021. The copyright holder for this preprint (which was not certified by peer review) is the author/funder, who has granted medRxiv a license to display the preprint in It is made available under a CC-BY-NC-ND 4.0 International license .

a)

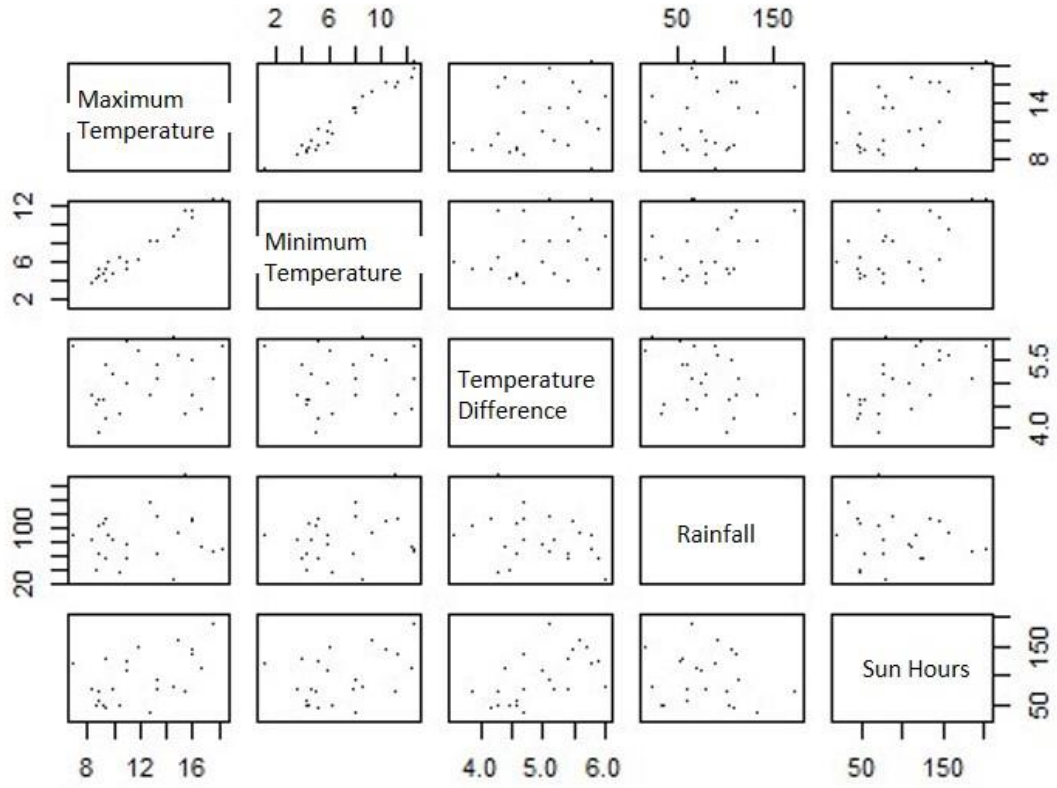

b)

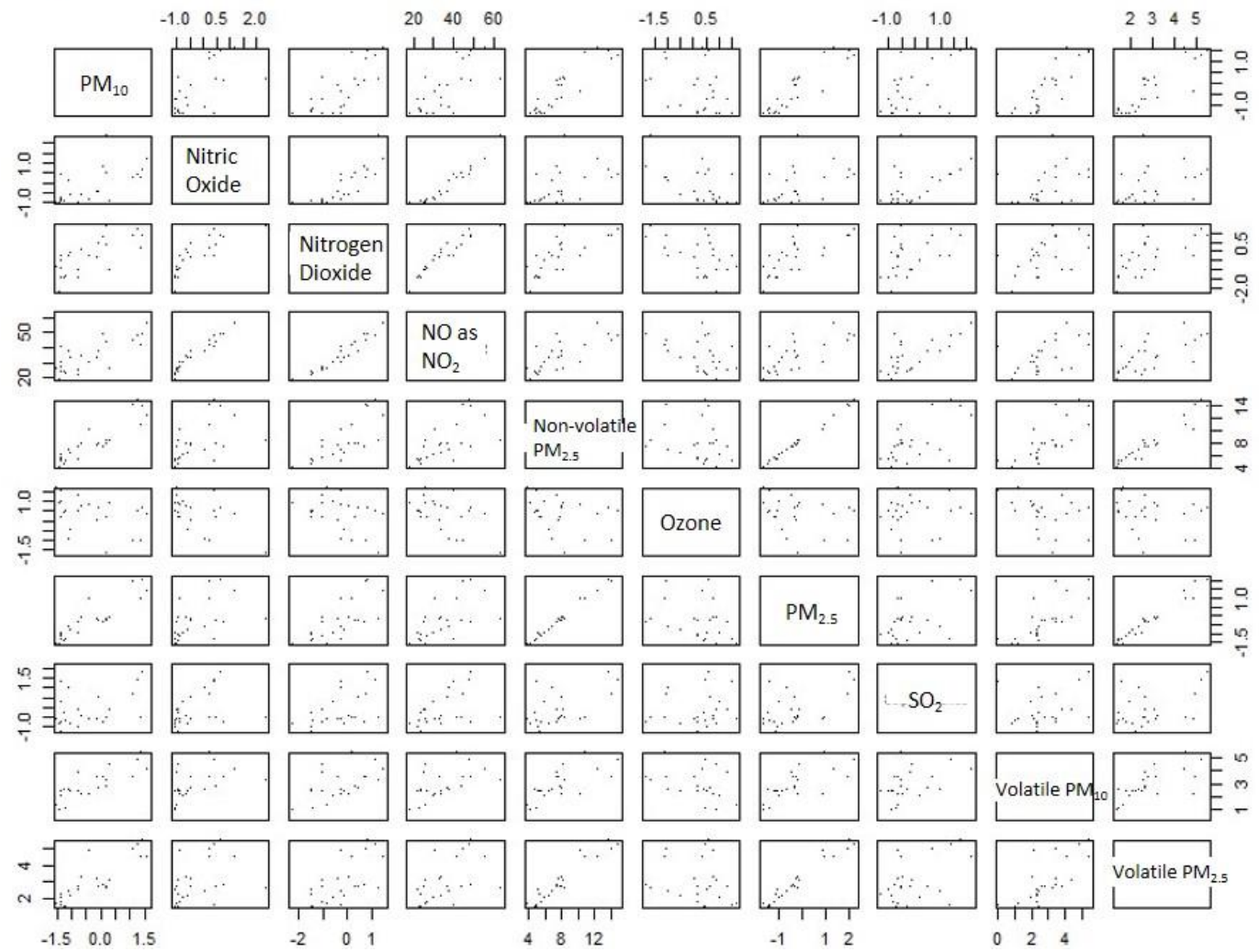

Supplementary Figure 3: a) Plots to determine collinearity of climate variables maximum temperature $\left({ }^{\circ} \mathrm{C}\right)$, minimum temperature $\left({ }^{\circ} \mathrm{C}\right)$, temperature difference $\left({ }^{\circ} \mathrm{C}\right)$, rainfall $(\mathrm{mm})$ and sun hours. Maximum and minimum temperature were strongly correlated. b) Plots to determine collinearity of air-quality variables $\left(\mu \mathrm{g} / \mathrm{m}^{-3}\right) \mathrm{PM}_{10}$, $\mathrm{NO}, \mathrm{NO}_{2}$, $\mathrm{NO}$ as $\mathrm{NO}_{2}$, non-volatile $\mathrm{PM}_{2.5}$, ozone, $\mathrm{PM}_{2.5}, \mathrm{SO}_{2}$, volatile $\mathrm{PM}_{10}$ and volatile $\mathrm{PM}_{2.5}$. $\mathrm{NO}_{\text {as }} \mathrm{NO}_{2}$ data mimics that of $\mathrm{NO}$ and $\mathrm{NO}_{2}$ separately. Non-volatile $\mathrm{PM}_{2.5}$ and volatile $\mathrm{PM}_{2.5}$ data were found to be combined within total $\mathrm{PM}_{2.5}$ data. Similarly, $\mathrm{PM}_{10}$ data was strongly correlated with volatile $\mathrm{PM}_{10}$ data. Limited collinearity exists between $\mathrm{PM}_{2.5}$ and $\mathrm{PM}_{10}$ and between $\mathrm{SO}_{2}, \mathrm{NO}$ and $\mathrm{NO}_{2}$. 
medRxiv preprint doi: https://doi.org/10.1101/2021.10.04.21264228; this version posted October 5, 2021. The copyright holder for this preprint (which was not certified by peer review) is the author/funder, who has granted medRxiv a license to display the preprint in It is made available under a CC-BY-NC-ND 4.0 International license .

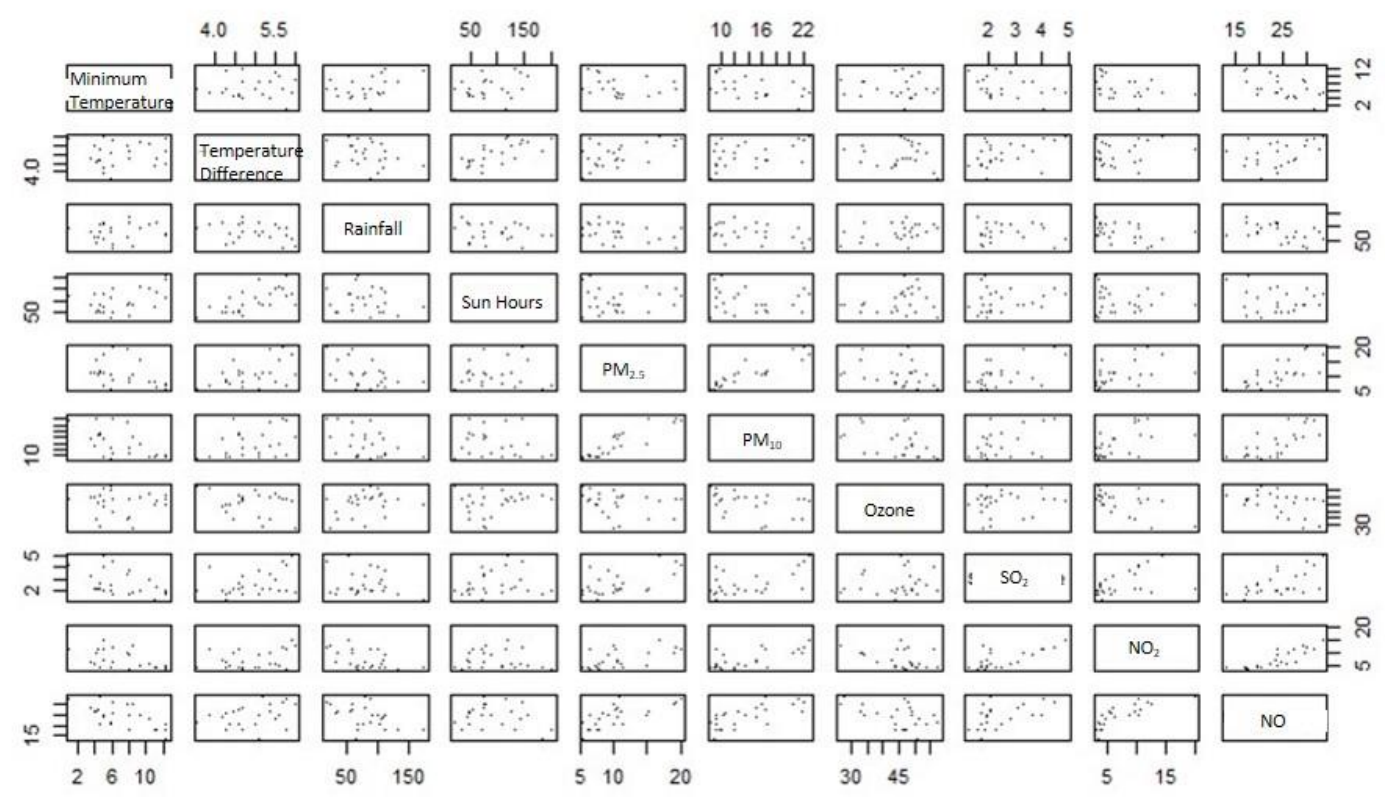

Supplementary Figure 4: Plots to determine collinearity of variables minimum temperature $\left({ }^{\circ} \mathrm{C}\right)$, temperature difference $\left({ }^{\circ} \mathrm{C}\right)$, rainfall $(\mathrm{mm})$, sun hours, $\mathrm{PM}_{2.5}\left(\mu \mathrm{g} / \mathrm{m}^{-3}\right), \mathrm{PM}_{10}\left(\mu \mathrm{g} / \mathrm{m}^{-3}\right)$, ozone $\left(\mu \mathrm{g} / \mathrm{m}^{-3}\right), \mathrm{SO}_{2}\left(\mu \mathrm{g} / \mathrm{m}^{-3}\right), \mathrm{NO}\left(\mu \mathrm{g} / \mathrm{m}^{-}\right.$ $\left.{ }^{3}\right)$ and $\mathrm{NO}_{2}\left(\mu \mathrm{g} / \mathrm{m}^{-3}\right)$. 